\title{
Tau Protein, A $\beta 42$ and S-100B Protein in Cerebrospinal Fluid of Patients with Dementia with Lewy Bodies
}

\author{
Brit Mollenhauer $^{\mathrm{a}}$ Lukas Cepek $^{\mathrm{a}}$ Mirko Bibl $^{\mathrm{b}}$ Jens Wiltfang ${ }^{\mathrm{d}}$ \\ Walter J. Schulz-Schaeffer ${ }^{c}$ Barbara Ciesielczyk ${ }^{a}$ Manuela Neumann ${ }^{e}$ \\ Petra Steinacker ${ }^{b}$ Hans A. Kretzschmar ${ }^{\text {e Sigrid Poser }}{ }^{a}$ \\ Claudia Trenkwalder ${ }^{f}$ Markus Otto $^{a}$ \\ Departments of a Neurology, ${ }^{b}$ Psychiatry and c Neuropathology, Georg August University Göttingen, Göttingen, \\ dDepartment of Psychiatry, Friedrich Alexander University Erlangen/Nuremberg, Erlangen, e Department of \\ Neuropathology, Ludwig Maximilians University Munich, Munich, and fGeorg August University Göttingen, \\ Paracelsus-Elena-Klinik, Kassel, Germany
}

\section{Key Words \\ Dementia with Lewy bodies - Alzheimer's disease • \\ Cerebrospinal fluid $\cdot$ Tau protein $\cdot A \beta 42 \cdot S-100 B$ \\ protein · Parkinson's disease $\cdot$ Laboratory marker}

\begin{abstract}
The intra vitam diagnosis of dementia with Lewy bodies (DLB) is still based on clinical grounds. So far no technical investigations have been available to support this diagnosis. As for tau protein and $\beta$-amyloid (1-42) $(A \beta 42)$, promising results for the diagnosis of Alzheimer's disease (AD) have been reported; we evaluated these markers and S-100B protein in cerebrospinal fluid (CSF), using a set of commercially available assays, of 71 patients with DLB, 67 patients with AD and 41 nondemented controls (NDC) for their differential diagnostic relevance. Patients with DLB showed significantly lower tau protein
\end{abstract}

The study was supported in part by a grant from the Bundesministerium für Gesundheit, Berlin, Germany, to Drs. M.O. and S.P. values compared to AD but with a high overlap of values. More prominent differences were observed in the comparison of DLB patients with all three clinical core features and $A D$ patients. $A \beta 42$ levels were decreased in the DLB and AD groups versus NDC, without significant subgroup differences. S-100B levels were not significantly different between the groups. Tau protein levels in CSF may contribute to the clinical distinction between DLB and $A D$, but the value of the markers is still limited especially due to mixed pathology. We conclude that more specific markers have to be established for the differentiation of these diseases.

Copyright @ 2005 S. Karger AG, Basel

\section{Introduction}

Dementia with Lewy bodies (DLB) is the second most common type of dementia. A definite diagnosis of DLB can only be made on the basis of neuropathology [1].

As DLB patients often suffer from neuroleptic sensitivity [2], there is a need to improve clinical diagnosis of DLB to prevent these patients from receiving the wrong

\begin{tabular}{ll}
\hline KARGER & ( ) 2005 S. Karger AG, Basel \\
1420-8008/05/0193-0164\$22.00/0 \\
$\begin{array}{l}\text { Fax +4161306 1234 } \\
\begin{array}{l}\text { E-Mail karger@karger.ch } \\
\text { www.karger.com }\end{array}\end{array}$ & $\begin{array}{l}\text { Accessible online at: } \\
\text { www.karger.com/dem }\end{array}$
\end{tabular}

Dr. Brit Mollenhauer

Neurologische Klinik und Poliklinik, Georg-August-Universität Göttingen Robert-Koch-Strasse 40, DE-37075 Göttingen (Germany)

Tel. +49 55139 8404, Fax +49 5513914449

E-Mailbmollenhauer@med.uni-goettingen.de 
medication. For Alzheimer's disease (AD), a typical cerebrospinal fluid (CSF) pattern of $\beta$-amyloid $(1-42)(A \beta 42)$ and tau protein was postulated. A decrease in $A \beta 42$ and an increase in tau protein levels have been found in most of the studies [3-6]. Total tau protein, the main structural component of neurofibrillary pathology, is assumed to be a marker of neuronal damage in CSF [7, 8], whereas A $\beta 42$ is the main component of $\mathrm{AD}$ plaques [3-5].

Elevated levels of the astroglial marker S-100B protein have been observed in acute neurological disease and possibly indicate damage to astroglial cells in these diseases [9]. Elevated levels of S-100B have also been reported in neurodegenerative diseases like AD [10], frontotemporal dementia [11,12] and amyotrophic lateral sclerosis [13]. High levels were reported in Creutzfeldt-Jakob disease and could even be seen in serum samples [14]. In these cases raised levels are considered to represent astroglial activation. Up to now no data has been available for the differential diagnostic value of S-100B protein in DLB patients.

For DLB, decreased A $\beta 42$ and normal tau levels were reported in small groups of clinically diagnosed patients $[15,16]$, but this could not be verified in selected patients diagnosed post mortem [17]. We have now evaluated tau protein, $A \beta 42$ and $\mathrm{S}-100 \mathrm{~B}$ protein in a larger group of patients with DLB, AD and in nondemented controls (NDC) to evaluate whether these markers will help to differentiate between $\mathrm{AD}$ and DLB.

\section{Materials and Methods}

\section{Patients with DLB}

The group of DLB patients comprised 2 'definite' cases, 63 'probable' cases and 6 cases with Parkinson's disease dementia (PDD). Clinical records from all patients were analyzed according to the clinical criteria of McKeith et al. [1]. At least two of the core symptoms (fluctuating cognitive decline, extrapyramidal signs, and visual hallucinations) are required for the diagnosis of 'probable' DLB. All cases included fulfilled the criteria for at least 'probable DLB'. Twentythree patients presented with two (group DLB-II) and 48 patients with all three core features (group DLB-III). All patients were hospitalized at least several days for the documentation of fluctuating cognition. Dementia was supported either by Mini Mental Status Examination (MMSE) [18] or extensive neuropsychological testing and medical history given by relatives. In 22 patients with DLB, MMSE was performed at the time of lumbar puncture. Hallucinations and parkinsonism could not be attributed to medication in all patients that were included. If parkinsonism had been present for a long time (more than 1 year) before dementia was diagnosed, such patients were classified according the established criteria as $\operatorname{PDD}(n=6)$. The other 65 cases were designated 'probable' DLB. All patients underwent brain imaging to exclude other diseases. Risk factors for vascular lesions were recorded.

Tau Protein, A $\beta 42$ and S-100B Protein in

Patients with Dementia with Lewy Bodies
In 2 cases, clinical diagnosis was confirmed by neuropathological examination using paraffin-embedded formalin-fixed brain tissue and immunochemistry. Distribution of Lewy bodies and frequency were evaluated on alpha-synuclein immunostains according to the consensus guidelines for the pathologic diagnosis of DLB [1].

\section{Patients with $A D$}

Additionally, we analyzed 67 AD patients and 41 nondemented controls. Diagnosis of AD was made according to the NINCDSADRDA work group criteria [19]. None of the AD patients suffered from hallucinations or extrapyramidal signs. All included patients were at least classified as 'probable' AD. Three cases of this group were neuropathologically verified using paraffin-embedded formalin-fixed brain tissue and immunochemistry.

Dementia was also diagnosed either with MMSE or extensive neuropsychological testing and history given by the relatives. In 45 patients with AD, MMSE was performed at the time of lumbar puncture. All patients underwent brain imaging to exclude other diseases. Risk factors for vascular lesions were recorded.

\section{Patients without Dementia}

The NDC group $(\mathrm{n}=41)$ consisted of patients with depression $(n=14)$, acute psychosis $(n=5)$, old cerebral ischemic lesions $(n=5)$, radicular syndromes $(n=3)$, alcoholic delirium $(n=2)$, multiple sclerosis $(\mathrm{n}=2)$ and 1 patient each with carpal tunnel syndrome, shoulder-hand syndrome, schizophrenia, diabetic neuropathy, myopathy, epileptic seizure, hydrocephalus, neuritis vestibularis, transient myelitis, and articular rheumatism.

Age at the time of lumbar puncture, sex distribution, duration of disease and MMSE scores of these groups are given in table 1.

\section{Tau Protein, $A \beta 42$ and $S-100 B$ Protein}

Samples of all groups were obtained by lumbar puncture. Aliquots for $\mathrm{A} \beta 42$ and tau protein were stored at $\pm 4^{\circ} \mathrm{C}$ and analyzed within 2 days. Aliquots for S-100B protein were stored at $-80^{\circ} \mathrm{C}$ until measurement.

All samples were analyzed using commercially available assays $[4,14,20-22]$ (tau protein and A $\beta 42$ : Innotest hTAU Antigen and Innotest $\beta$-Amyloid $_{(1-42)}$, Innogenetics, Ghent, Belgium; S-100B protein: Sangtec Medical, Bromma, Sweden). In most reports, normal levels for tau protein were below $450 \mathrm{pg} / \mathrm{ml}$ [4-7]. A $\beta 42$ should be above $450 \mathrm{pg} / \mathrm{ml}$ in nondemented patients [3-6] and S-100B levels were below $2 \mathrm{ng} / \mathrm{ml}$ in control CSF samples [14, 22].

Tau protein was analyzed in 179 cases. A $\beta 42$ levels were determined in 173 patients and S-100B protein was measured in $113 \mathrm{CSF}$ samples (table 2).

\section{Statistical Analysis}

The distribution of CSF marker levels between subgroups of the study population was compared by nonparametric rank tests (for two groups: Wilcoxon-Mann-Whitney U test, for more than two groups: Kruskal-Wallis test). 
Table 1. Epidemiological data, MMSE score and clinical classification

\begin{tabular}{|c|c|c|c|}
\hline & DLB & $\mathrm{AD}$ & NDC \\
\hline Age at the time of lumbar puncture ${ }^{1}$, years & $\begin{array}{l}\text { 50-89 } \\
\text { (median: 72) }\end{array}$ & $\begin{array}{l}45-86 \\
\text { (median: 66) }\end{array}$ & $\begin{array}{l}45-56 \text { years } \\
\text { (median: } 51 \text { years) }\end{array}$ \\
\hline Sex (m:f) & $40: 31$ & $23: 44$ & $15: 26$ \\
\hline Duration of disease ${ }^{2}$, months & $\begin{array}{l}\text { 1-180 } \\
\text { (median: 16.5) }\end{array}$ & $\begin{array}{l}\text { 6-80 } \\
\text { (median: 24) }\end{array}$ & not applicable \\
\hline MMSE score $^{2}$ & $\begin{array}{l}\text { 11-25 } \\
\text { (median: 16.5) }\end{array}$ & $\begin{array}{l}1-26 \\
\text { (median: 17.5) }\end{array}$ & not applicable \\
\hline Exact diagnosis & $\begin{array}{l}63 \text { probable DLB } \\
6 \text { PDD } \\
2 \text { definite DLB }\end{array}$ & $\begin{array}{c}64 \text { probable } \mathrm{AD} \\
3 \text { definite } \mathrm{AD}\end{array}$ & see text \\
\hline
\end{tabular}

$\mathrm{p}<0.001$ between NDC and AD/DLB.

2 Before lumbar puncture.

Table 2. Overview of analysis of markers and groups

\begin{tabular}{|c|c|c|c|c|c|c|c|c|c|}
\hline & \multicolumn{3}{|l|}{ DLB } & \multicolumn{3}{|l|}{$\mathrm{AD}$} & \multicolumn{3}{|l|}{ NDC } \\
\hline & median & range & $\mathrm{n}$ & median & range & $\mathrm{n}$ & median & range & $\mathrm{n}$ \\
\hline Tau protein*, $\mathrm{pg} / \mathrm{ml}$ & 333 & $97-1,579$ & 71 & 543 & $133-1,200$ & 67 & 130 & $59-486$ & 41 \\
\hline $\mathrm{A} \beta 42^{* *}, \mathrm{pg} / \mathrm{ml}$ & 403 & $100-1,339$ & 71 & 382 & $119-1,011$ & 61 & 818 & $485-1,322$ & 41 \\
\hline $\mathrm{S}-100 \mathrm{~B}$ protein, $\mathrm{ng} / \mathrm{ml}$ & 2.28 & $0.83-6.76$ & 59 & 2.33 & $0.71-5.18$ & 32 & 1.87 & $108-2.82$ & 22 \\
\hline
\end{tabular}

$* \mathrm{p}<0.001$ between AD/DLB and NDC and $\mathrm{p}<0.05$ between AD and DLB; $* * \mathrm{p}<0.001$ between AD/DLB and NDC.

\section{Results}

\section{Tau Protein}

Tau protein levels ranged between 97 and $1,579 \mathrm{pg} / \mathrm{ml}$ (median: $333 \mathrm{pg} / \mathrm{ml}$ ) in the DLB group, between 133 and 1,200 pg/ml (median: $543 \mathrm{pg} / \mathrm{ml}$ ) in the AD group and between 59 and $486 \mathrm{pg} / \mathrm{ml}$ (median: $130 \mathrm{pg} / \mathrm{ml}$ ) in the NDC group (fig. 1). 43 DLB patients showed tau levels below and 28 showed tau levels above $450 \mathrm{pg} / \mathrm{ml}$.

There were significantly higher levels of tau protein in the AD and DLB groups compared to the NDC group $(\mathrm{p}<$ $0.001)$. Tau protein levels were higher in the AD group compared to the DLB group $(\mathrm{p}=0.003)$.

\section{$\beta$-Amyloid $(1-42)$}

A $\beta 42$ levels ranged between 100 and $1,339 \mathrm{pg} / \mathrm{ml}$ (median: $403 \mathrm{pg} / \mathrm{ml}$ ) in the DLB group, between 191 and
1,011 pg/ml (median: $382 \mathrm{pg} / \mathrm{ml}$ ) in the AD patients and between 485 and 1,322 pg/ml (median: $818 \mathrm{pg} / \mathrm{ml}$ ) in the NDC group (fig. 1).

$A \beta 42$ levels were significantly decreased in AD and DLB compared to NDC $(\mathrm{p}<0.001)$. There was no statistically significant discrimination between $\mathrm{AD}$ and DLB by $\mathrm{A} \beta 42(\mathrm{p}=0.85)$.

\section{S-100B Protein}

The levels of $\mathrm{S}-100 \mathrm{~B}$ protein ranged between 0.83 and $6.76 \mathrm{ng} / \mathrm{ml}$ (median: $2.28 \mathrm{ng} / \mathrm{ml}$ ) in the DLB patients, between 0.71 and $5.18 \mathrm{ng} / \mathrm{ml}$ (median: $2.33 \mathrm{ng} / \mathrm{ml}$ ) in the AD patients and between 1.08 and $2.82 \mathrm{ng} / \mathrm{ml}$ (median: $1.87 \mathrm{ng} / \mathrm{ml}$ ) in the control group (fig. 1). S100-B protein was analyzed in 22 patients of the NDC group: Four patients with depression showed levels between 1.26 and $2.51 \mathrm{ng} / \mathrm{ml}$ (median: $2.14 \mathrm{ng} / \mathrm{ml}$ ). Five patients with isch- 


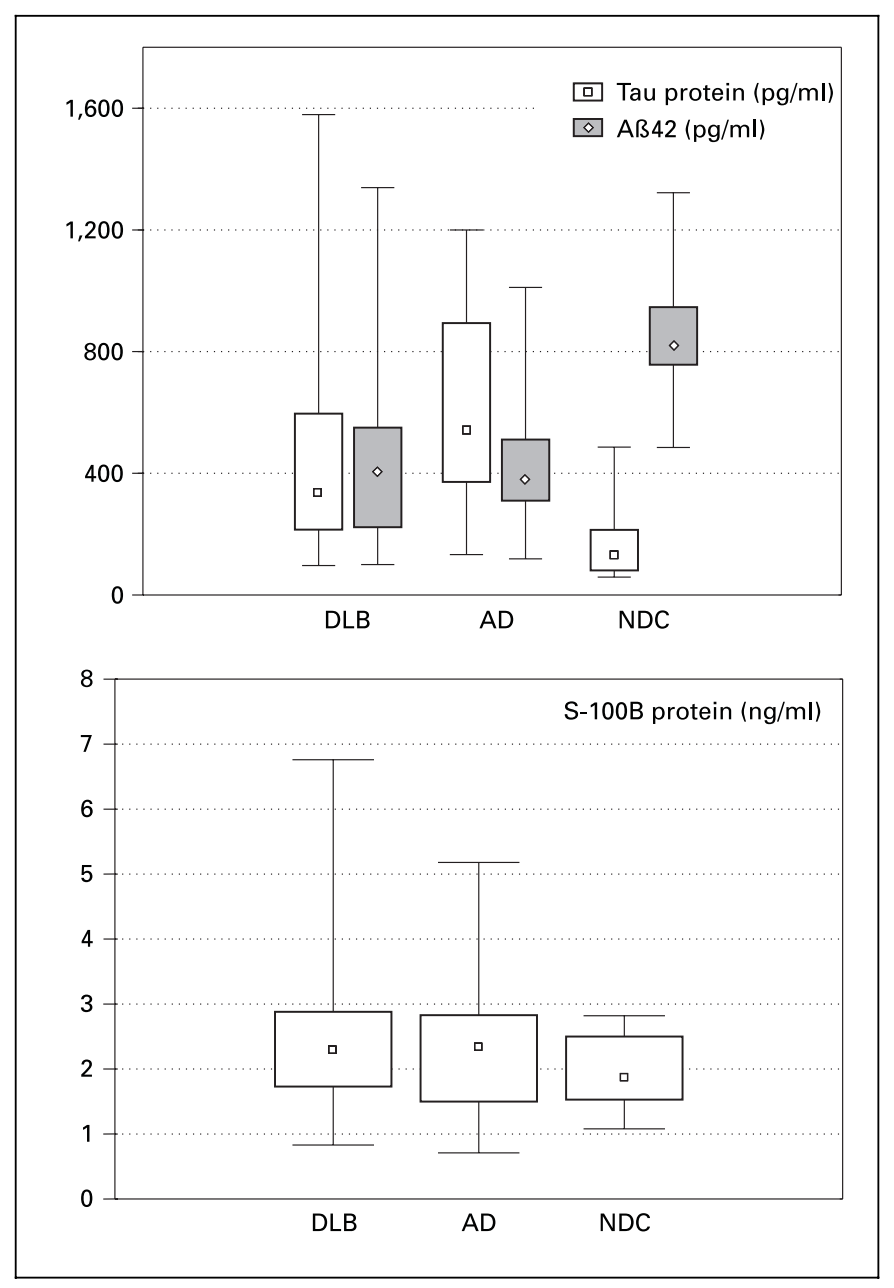

Fig. 1. Box plots of tau protein $(\mathrm{ng} / \mathrm{ml}), \mathrm{A} \beta 42(\mathrm{pg} / \mathrm{ml})$, and $\mathrm{S}-100 \mathrm{~B}$ protein $(\mathrm{ng} / \mathrm{ml})$ in CSF of patients suffering from DLB, AD and NDC ( $\square$ median, $\square 25-75 \%$, I min-max).

emia had levels between 1.53 and $2.82 \mathrm{ng} / \mathrm{ml}$ (median: $2.66 \mathrm{ng} / \mathrm{ml})$. The levels of 5 patients with peripheral neurological disorder varied between 1.08 and 2.51 (median: $2.1 \mathrm{ng} / \mathrm{ml}$ ). S100B level of the patient with acute psychosis was $1.37 \mathrm{ng} / \mathrm{ml}$, with myopathy $2.55 \mathrm{ng} / \mathrm{ml}$, with hydrocephalus $2.6 \mathrm{ng} / \mathrm{ml}$, neuronitis vestibularis $2.35 \mathrm{ng} / \mathrm{ml}$, epileptic seizures $1.53 \mathrm{ng} / \mathrm{ml}$, articular rheumatism 1.82 $\mathrm{ng} / \mathrm{ml}$, transient myelitis $2.6 \mathrm{ng} / \mathrm{ml}$, and the patient with alcoholic delirium showed an S100B level of $1.26 \mathrm{ng} / \mathrm{ml}$.

S-100B neither discriminated between NDC and the two dementia groups $(p=0.36$ : AD vs. NDC; $p=0.11$ : DLB vs. NDC) nor between AD and DLB ( $p=0.699)$.

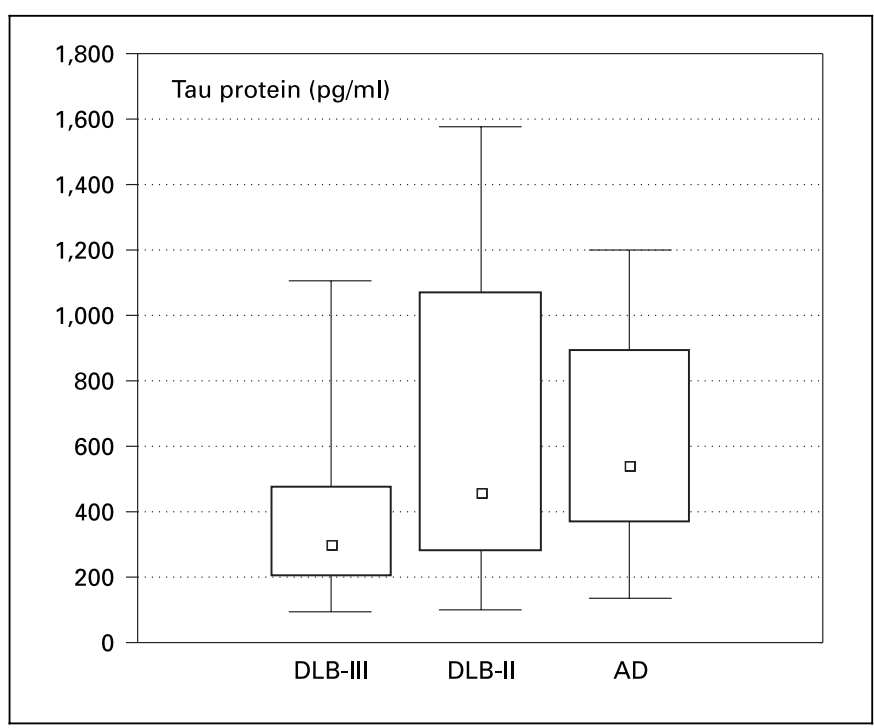

Fig. 2. Tau protein $(\mathrm{ng} / \mathrm{ml})$ in patients suffering from $A D$ and $D L B$ with two core features [1] (DLB-II, $\mathrm{n}=23$ ) and with three core features (DLB-III, $\mathrm{n}=48$ ) ( $\square$ median, $\square 25-75 \%$, I min-max).

\section{Analysis of the Groups according to Clinical Presentation}

Variation of MMSE and duration of disease between $\mathrm{AD}$ and DLB groups was not significant $(\mathrm{p}>0.05)$, nor was the variation of age at the time of lumbar puncture between AD and DLB ( $>0.05)$. Age at the time of lumbar puncture was significantly different between the demented groups (AD and DLB) and the NDC group ( $\mathrm{p}<$ $0.001)$.

In the group of DLB patients presenting with two core features (DLB-II, $\mathrm{n}=23$ ), tau protein ranged between 99 and $1,579 \mathrm{pg} / \mathrm{ml}$ (median: $448 \mathrm{pg} / \mathrm{ml}$ ). Tau protein levels in the DLB-III group (patients fulfilling all three main criteria, $\mathrm{n}=48$ ) ranged between 97 and $1,104 \mathrm{pg} / \mathrm{ml}(\mathrm{me}-$ dian: $324 \mathrm{pg} / \mathrm{ml}$ ) (fig. 2). Tau protein levels of the DLB-III group were significantly lower compared to the $\mathrm{AD}$ group $(\mathrm{p}<0.001)$ but not between DLB-II and AD $(p=0.89)$. $\mathrm{S}-100 \mathrm{~B}$ and $\mathrm{A} \beta 42$ levels did not show subgroup-specific alterations.

In the group of 6 patients with PDD values, tau protein levels ranged between 195 and $377 \mathrm{pg} / \mathrm{ml}$ (median: $235 \mathrm{pg} / \mathrm{ml}$ ). In comparison, tau protein levels in the group of 63 patients with 'probable' DLB ranged between 97 and $1,579 \mathrm{pg} / \mathrm{ml}$ (median: $356 \mathrm{pg} / \mathrm{ml}$ ). Again S-100B and $A \beta 42$ levels did not show subgroup-specific alterations.

We found slightly higher S-100B levels in the DLB group with MMSE $>18$ (mean: $2.4 \mathrm{ng} / \mathrm{ml}$ ) compared to the group with MMSE $<18$ (mean: $2.0 \mathrm{ng} / \mathrm{ml}$ ).

Dement Geriatr Cogn Disord 2005;19:164-170 


\section{Analysis of Neuropathologically Verified Cases}

In the CSF of the 2 'definite' DLB cases, tau protein was 466 and $289 \mathrm{pg} / \mathrm{ml}$, respectively and $\mathrm{A} \beta 42$ was 542 and $333 \mathrm{pg} / \mathrm{ml}$, respectively. S-100B protein was measured only in 1 definite DLB case, at $1.62 \mathrm{ng} / \mathrm{ml}$. Both patients were clinically classified as 'probable' DLB and fulfilled all three core criteria. The 3 'definite' AD cases presented with tau protein levels between 332 and $1,200 \mathrm{pg} / \mathrm{ml}$ and S-100B protein levels between $3.4 \mathrm{ng} / \mathrm{ml}$ and $2.5 \mathrm{ng} / \mathrm{ml}$ (A $\beta 42$ was not done).

\section{Analysis according to Insulin Medication}

Twelve patients in the DLB group were known to have diabetes mellitus. Two of these used insulin medication. Tau protein values for these patients were 259 and $300 \mathrm{pg} / \mathrm{ml}$, and S-100B protein levels were 2.17 and $2.85 \mathrm{ng} / \mathrm{ml}$. A 342 levels were 704 and $698 \mathrm{pg} / \mathrm{ml}$ in the 2 DLB patients with insulin-dependent diabetes mellitus and ranged between 191 and $795 \mathrm{pg} / \mathrm{ml}$ (median: $519 \mathrm{pg} /$ $\mathrm{ml}$ ) in the DLB group with non-insulin-dependent diabetes mellitus. There were 2 patients with $\mathrm{AD}$ and diabetes mellitus. One was insulin-dependent. This patient showed a tau protein value of $667 \mathrm{pg} / \mathrm{ml}, \mathrm{A} \beta 42$ level was $847 \mathrm{pg} / \mathrm{ml}$ and S-100B protein was $2.05 \mathrm{ng} / \mathrm{ml}$.

\section{Discussion}

This is the first study in which CSF levels of tau protein, $A \beta 42$ and $S-100 B$ protein were analyzed in a larger group of patients with DLB in comparison with AD patients. In smaller studies, discrepant laboratory findings for tau protein and $A \beta 42$ were found [15-17, 23-26]. In two studies, it was suggested that DLB might be differentiated from $\mathrm{AD}$ by tau protein and $\mathrm{A} \beta 42[15,16]$. However, in both studies no analysis according to clinical core features was made and, surprisingly, decreases in $A \beta 42$ were found in the clinical control group [16]. In our population of clinically well-defined DLB and AD patients, the CSF levels of tau protein discriminated significantly between AD and DLB and NDC. A $\beta 42$ and S-100B protein in DLB did not differ significantly from the AD group.

We are aware that our study group is mainly based on clinical diagnoses. Molecular genetic studies have revealed that both $\mathrm{AD}$ and DLB share an elevated ApoE4 allele frequency [27]. The analysis of further laboratory markers might be stratified according to genetic markers. However, because of the homogeneity of our results, this might not be necessary for tau protein, $A \beta 42$ and S-100B protein. We included solely patients with enough clinical information and detailed medical history given by the relatives to classify them as 'probable' DLB according to established criteria.

Up to now, no data have been available on S-100B levels in DLB. In a case report of neurodegenerative dementia, it was shown that S-100B levels correlate positively with disease progression, possibly due to gliosis, while tau protein can decrease due to neuronal loss [28].

It has recently been shown that insulin can increase A $\beta 42$ levels in CSF [29], and in fact 3 of our patients who suffered from insulin-dependent diabetes mellitus had higher levels of $A \beta 42$.

DLB patients often present with extrapyramidal signs at onset, not only in PDD. The onset of dementia represents the onset of cortical neuronal damage, which may apparently lead to the elevation of markers indicating neurodegeneration (e.g. tau protein). Our findings support this hypothesis. Massive neuronal loss occurs in many of the DLB cortical regions to a similar extent to that seen in $\mathrm{AD}$, in addition to the classical sites of neuronal death in the brainstem, as in PD [30]. Patients with $\mathrm{PD}$ alone without dementia showed tau protein and $\mathrm{A} \beta 42$ levels comparable to NDC $[15,23]$. Our patients with PDD presented with lower tau-protein levels than DLB patients. Our group with PDD is certainly too small for a valid comparison. However, our observation supports the idea that patients with parkinsonism, visual hallucinations (which may reflect a medication effect) and elevated CSF levels of tau protein are more likely to be DLB patients than patients with PD.

All patients of our DLB group exhibited at least two core features and were classified as having 'probable' DLB, but the majority of our patients exhibited all three core features with fluctuating cognition, spontaneous extrapyramidal signs and visual hallucinations. These DLB patients showed significantly lower tau protein levels compared to the AD patients of our group. Reciprocally $74 \%$ of our DLB patients with tau protein levels below $450 \mathrm{pg} / \mathrm{ml}$ showed all three core features. According to the literature, in autopsy-proven DLB patients $73 \%$ showed concomitant AD pathology with higher Braak stages (3-6) and only $27 \%$ with lower Braak stages (0-2). The clinical diagnostic accuracy for these autopsy-proven DLB cases was higher for patients with low (75\%) compared to high (39\%) Braak stage [30-32]. Our patients, fulfilling all three core criteria (DLB-III), have lower tau levels, whereas patients with only two or less core features may represent a group with AD mixed pathology, pronounced neuronal cell loss and therefore higher tau levels. The fact that tau protein discriminates between our DLB-III group, 
showing all three core features, and AD patients is of low clinical relevance since e.g. patients with mixed pathology may also show neuroleptic sensitivity. CSF of DLB patients with mild tau pathology and with mild neuron loss will further need to be examined.

Whether or not other markers like phospho-tau and the analysis of the spectrum of amyloid peptides will help in this differentiation must be seen in separate studies [26, $33,34]$. We conclude from our results that the value of the markers measured here for the differentiation of DLB from $\mathrm{AD}$ is limited, but seems to be of differential diagnostic relevance for PDD and DLB.

\section{References}

1 McKeith IG, Galasko D, Kosaka K, Perry EK, Dickson DW, Hansen LA, Salmon DP, Lowe J, Mirra SS, Byrne EJ, Lennox G, Quinn NP, Edwardson JA, Ince PG, Bergeron C, Burns A, Miller BL, Lovestone S, Collerton D, Jansen EN, Ballard C, de Vos RA, Wilcock GK, Jellinger KA, Perry RH: Consensus guidelines for the clinical and pathologic diagnosis of dementia with Lewy bodies (DLB): Report of the consortium on DLB international workshop. Neurology 1996;47:1113-1124.

2 McKeith I, Fairbairn A, Perry R, Thompson P, Perry E: Neuroleptic sensitivity in patients with senile dementia of the Lewy-body type. BMJ 1992;305:673-678.

3 Motter R, Vigo-Pelfrey C, Kholodenko D, Barbour R, Johnson-Wood K, Galasko D, Chang L, Miller B, Clark C, Green R, et al: Reduction of $\beta$-amyloid peptide 42 in the cerebrospinal fluid of patients with Alzheimer's disease. Ann Neurol 1995;38:643-648.

4 Hulstaert F, Blennow K, Ivanoiu A, Schoonderwaldt HC, Riemenschneider M, De Deyn PP, Bancher C, Cras P, Wiltfang J, Mehta PD, Iqbal K, Pottel H, Vanmechelen E, Vanderstichele $\mathrm{H}$ : Improved discrimination of AD-patients using $\beta$-amyloid (1-42) and tau levels in CSF. Neurology 1999;52:1555-1562.

5 Galasko D: Cerebrospinal fluid levels of A beta 42 and tau: Potential markers of Alzheimer's disease. J Neural Transm Suppl 1998;53:209_ 221.

6 Sunderland T, Linker G, Mirza N, Putnam KT, Friedman DL, Kimmel LH, Bergeson J, Manetti GJ, Zimmermann M, Tang B, Bartko JJ, Cohen RM: Decreased beta-amyloid 1-42 and increased tau levels in cerebrospinal fluid of patients with Alzheimer disease. JAMA 2003;289:2094-3003.

7 Otto M, Wiltfang J, Tumani H, Zerr I, Lantsch M, Kornhuber J, Weber T, Kretzschmar HA, Poser S: Elevated levels of tau-protein in cerebrospinal fluid of patients with CreutzfeldtJakob disease. Neurosci Lett 1997;225:210 212.

8 Otto M, Wiltfang J, Cepek L, Neumann M, Mollenhauer B, Steinacker P, Ciesielczyk B, Schulz-Schaeffer W, Kretzschmar HA, Poser S: Tau protein and 14-3-3 protein in the differential diagnosis of Creutzfeldt-Jakob disease. Neurology 2002;58:192-197.
9 Berger RP, Pierce MC, Wisniewski SR, Adelson PD, Clark RS, Ruppel RA, Kochanek PM: Neuron-specific enolase and S100B in cerebrospinal fluid after severe traumatic brain injury in infants and children. Pediatrics 2002;109: E31.

10 Peskind ER, Griffin WS, Akama KT, Raskind MA, Van Eldik LJ: Cerebrospinal fluid S100B is elevated in the earlier stages of Alzheimer's disease. Neurochem Int 2001;39:409-413.

11 Green AJ, Harvey RJ, Thompson EJ, Rossor $\mathrm{MN}$ : Increased S100beta in the cerebrospinal fluid of patients with frontotemporal dementia. Neurosci Lett 1997;235:5-8.

12 Maeck L, Meller J, Otto M, Stiens G, Wiltfang J, Stoppe G: A beta peptide 1-42, Tau protein and S-100B protein level in cerebrospinal fluid of three patients with primary progressive aphasia. Neurosci Lett 2002;333:33-36.

13 Sussmuth SD, Tumani H, Ecker D, Ludolph AC: Amyotrophic lateral sclerosis: Disease stage related changes of tau protein and $\mathrm{S} 100$ beta in cerebrospinal fluid and creatine kinase in serum. Neurosci Lett 2003;353:57-60.

14 Otto M, Stein H, Szudra A, Zerr I, Bodemer M, Gefeller O, Poser S, Kretzschmar HA, Mader M, Weber T: S-100 protein concentration in the cerebrospinal fluid of patients with Creutzfeldt-Jakob disease. J Neurol 1997;244:566570.

15 Kanemaru K, Kameda N, Yamanouchi H: Decreased CSF amyloid $\beta 42$ and normal tau levels in dementia with Lewy bodies. Neurology 2000;54:1875-1876.

16 Gomez-Tortosa E, Gonzalo I, Fanjul S, Sainz MJ, Cantarero S, Cemillan C, Yebenes JG, del Ser T: Cerebrospinal fluid markers in dementia with Lewy bodies compared with Alzheimer disease. Arch Neurol 2003;60:1218-1222.

17 Tschampa HJ, Schulz-Schaeffer W, Wiltfang J, Poser S, Otto M, Neumann M, Kretzschmar HA: Decreased CSF amyloid 42 and normal tau levels in dementia with Lewy bodies. Neurology 2001;56:576.

18 Folstein MF, Folstein SE, McHugh PR: 'Minimental state': A practical method for grading the cognitive state of patients for the clinician. J Psychiatr Res 1975;12:189-198.
19 McKhann G, Drachman D, Folstein M, Katzman R, Price D, Stadlan EM: Clinical diagnosis of Alzheimer's disease: Report of the NINCDS-ADRDA Work Group under the auspices of Department of Health and Human Services Task Force on Alzheimer's disease. Neurology 1984;34:939-944.

20 Citron M, Westaway D, Xia W, Carlson G, Diehl T, Levesque G, Johnson-Wood K, Lee M, Seubert P, Davis A, Kholodenko D, Motter R, Sherrington R, Perry B, Yao H, Strome R, Lieberburg I, Rommens J, Kim S, Schenk D, Fraser P, St George Hyslop P, Selkoe DJ: Mutant presenilins of Alzheimer's disease increase production of 42-residue amyloid $\beta$-protein in both transfected cells and transgenic mice. Nat Med 1997;3:67-72.

21 Citron M, Westaway D, Xia W, Carlson G, Diehl T, Levesque G, Johnson-Wood K, Lee M, Seubert P, Davis A, Kholodenko D, Motter R, Sherrington R, Perry B, Yao H, Strome R, Lieberburg I, Rommens J, Kim S, Schenk D, Fraser P, St George Hyslop P, Selkoe DJ: Amyloid precursor protein processing and A $\beta 42$ deposition in transgenic mouse model of $\mathrm{Alz}$ heimer's disease. Proc Natl Acad Sci USA 1997;94:1550-1555.

22 Aurell A, Rosengren LE, Wikkelsö C, Nordberg G, Haglid KG: The S-100 protein in cerebrospinal fluid: A simple ELISA method. J Neurol Sci 1998;89:157-164.

23 Arai H, Terajima M, Miura M, Higuchi S, Muramatsu T, Matsushita S, Machida N, Nakagawa T, Lee VM, Trojanowski JQ, Sasaki H: Effect of genetic risk factors and disease progression on the cerebrospinal fluid tau levels in Alzheimer's disease. J Am Geriatr Soc 1997; 45:1228-1231.

24 Molina L, Touchon J, Herpe M, Lefranc D, Duplan L, Cristol JP, Sabatier R, Vermersch P, Pau B, Mourton-Gilles C: Tau and Apo E in CSF: Potential aid for discriminating Alzheimer's disease from other dementias. Neuroreport 1999;10:3491-3495.

25 Sjogren M, Davidsson P, Tullberg M, Minthon L, Wallin A, Wikkelso C, Granerus AK, Vanderstichele $\mathrm{H}$, Vanmechelen $\mathrm{E}$, Blennow $\mathrm{K}$ : CSF levels of tau, beta-amyloid (1-42) and GAP-43 in frontotemporal dementia, other types of dementia and normal aging. J Neural Transm 2000;107:563-579. 
26 Parnetti L, Lanari A, Amici S, Gallai V, Vanmechelen E, Hulstaert F: CSF phosphorylated tau is a possible marker for discriminating Alzheimer's disease from dementia with Lewy bodies. Phospho-Tau International Study Group. Neurol Sci 2001;22:77-78.

27 Arai H, Higuchi S, Muramatsu T, Iwatsubo T, Sasaki H, Tronajowski JQ: Apolipoprotein E gene in diffuse Lewy body disease with or without co-existing Alzheimer's disease. Lancet 1994;344:1307.

28 Mollenhauer B, Serafin S, Zerr I, Steinhoff BJ, Otto M, Scherer M, Schulz-Schaeffer WJ, Poser S: Diagnostic problems during late course in Creutzfeldt-Jakob disease. J Neurol 2002;250: 629-630.
29 Watson GS, Peskind ER, Asthana S, Purganan K, Wait C, Chapman D, Schwartz MW, Plymate S, Craft S: Insulin increases CSF A $\beta 42$ levels in normal older adults. Neurology 2003; 60:1899-1903.

30 Hansen LA, Samuel W: Criteria for Alzheimer's disease and the nosology of dementia with Lewy bodies. Neurology 1997;48:126132.

31 Braak H, Braak E: Neuropathological staging of Alzheimer-related changes. Acta Neuropathol 1991;82:239-259.

32 Merdes AR, Hansen LA, Jeste DV, Galasko D, Hofstetter CR, Ho GJ, Thal LJ, Corey-Bloom $\mathrm{J}$ : Influence of Alzheimer pathology on clinical diagnostic accuracy in dementia with Lewy bodies. Neurology 2003;60:1586-1590.
33 Itoh $\mathrm{N}$, Arai $\mathrm{H}$, Urakami K, Ishiguro K, Ohno H, Hampel H, Buerger K, Wiltfang J, Otto M, Kretzschmar H, Moeller HJ, Imagawa M, Kohno H, Nakashima K, Kuzuhara S, Sasaki H, Imahori K: Large-scale, multicenter study of cerebrospinal fluid tau protein phosphorylated at serine 199 for antemortem diagnosis of $\mathrm{Alz}$ heimer's disease. Ann Neurol 2001;50:150 156.

34 Maddalena A, Papassotiropoulos A, MullerTillmanns B, Jung HH, Hegi T, Nitsch RM, Hock C: Biochemical diagnosis of Alzheimer disease by measuring the cerebrospinal fluid ratio of phosphorylated tau protein to betaamyloid peptide 42. Arch Neurol 2003;60: 1202-1206 